\title{
TRANSNATIONAL LAW AND LEGAL EDUCATION
}

\section{Maureen Irish ${ }^{*}$}

On September 20-21, 2013, the Faculty of Law, University of Windsor held a conference on Justice Beyond the State: Transnationalism and Law. ${ }^{1}$ Authors and commentators discussed topics in public and private international law, comparative law, non-state law and legal pluralism. Some contributions from the conference appear in this volume of the Windsor Yearbook of Access to Justice. Several conference papers are published in the Arizona Journal of International and Comparative Law. ${ }^{2}$

In our world, it is a commonplace that legal questions may present ties to more than one state. Some matters, such as environmental issues, are inherently transboundary in scope. In addition, it is wellunderstood that private parties are significantly involved in global relations. Individuals, groups and enterprises have diverse cross-border connections that are familial, cultural, religious, social and economic.

In the first lecture in my Conflicts course, I start by asking students in the class how many of them have ever walked down a street in another country. All hands go up. The questions continue with various sorts of cross-border involvements, until the last question, which is something like "How many of you were born in the province of Ontario, have never left Ontario, have no family members living outside Ontario, have never purchased anything that was shipped to you from outside Ontario and have never spoken to a foreigner?" At this point, no hands are raised. This is the "Welcome to the Real World" exercise. Its contents could vary in classes at law schools elsewhere. Some legal systems may be particularly cross-border in operation, especially in federations such as Canada where private law is a matter of provincial, sub-federal jurisdiction. For most people in most societies around the world, some connection across borders is likely part of the ordinary experience of law.

Transnational law reflects and responds to these links between the domestic and the foreign. In 1956, Philip C. Jessup described transnational law as including public international law, private international law and any law that "regulates actions or events that transcend national frontiers." 3 The description is very wide, covering matters that may arise in domestic courts or before various international tribunals, and issues that engage rules from a combination of sources that are neither solely domestic nor international. The area of inquiry includes public law and regulation, private law, relationships to religious and kinship law, non-state rules of practice and commercial standardization, and general attention to custom and pluralism.

A major component of current transnational legal thinking is the significant presence of private international law, in response to the geographic diversity of ordinary life. In private international law,

* Faculty of Law, University of Windsor

1 The conference was sponsored by the Transnational Law and Justice Network at the Faculty of Law. Co-organizers were Professors Maureen Irish, Myra Tawfik and Marcia Valiante. Research support and student assistance during the conference were provided by Erica Lindberg, Maria Habib and Aram Daniel Kerkonian. We are grateful for the dedicated administrative assistance of Cristina Corio. The conference was made possible by funding from the Law Foundation of Ontario, the Windsor Faculty of Law, the Canadian Council on International Law and Alexa Translations.

2 We thank Editor-in-Chief Eddie Walneck, the editorial board of the Arizona Journal of International and Comparative Law, and especially Professor David Gantz, for facilitating this cross-border initiative.

3 Philip C Jessup, Transnational Law (New Haven: Yale University Press, 1956) at 4. 
the foreign becomes part of domestic law, when foreign judgments are recognized by domestic courts or when foreign law is applied under choice of law rules. The past few decades have seen much ferment and change on these topics, within Canada and elsewhere. In its ground-breaking 1990 decision in Morguard, ${ }^{4}$ the Supreme Court of Canada embarked on a thorough reworking of the law on court jurisdiction and enforcement of foreign judgments. Many debates have ensued over the reasons motivating reform, ${ }^{5}$ the space reserved for domestic public policy, the role of coordination among courts, and the interaction between comity and accessibility of judicial remedy. The Court has pursued this reform in light of the perceived goal of modern private international law, which it expressed recently as "to facilitate exchanges and communications between people in different jurisdictions that have different legal systems.”6

Law that transcends national frontiers moves beyond territorial definitions of sovereignty in public international law. When facts cross borders, so too does regulation, in its effect and in its reason for being. Law applied extraterritorially reaches non-citizens as well as citizens. When law is assessed for its legitimacy and fairness, it can be difficult to identify the link to the relevant public. Important questions are raised over democratic legitimacy, and the rights and responsibilities of private parties as they move across national boundaries.

In a transnational context, judges in domestic courts may be presented with arguments that refer to rules of public international law or decisions of courts from other states. Transjudicialism presents opportunities and challenges in many areas, as judges decide whether and how to make use of these materials for assistance in interpretation. ${ }^{7} \mathrm{~A}$ view that looks beyond the state moves past positive law to consider sources of law in pluralism and other legal traditions, as well as normativity arising from soft law, custom and non-legal sources. The transnational focus then considers theories of the relationship

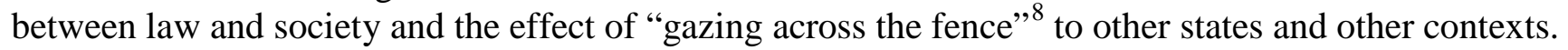

In law schools around the world and especially in North America, a recent trend in curriculum reform has been to promote transnational legal studies to prepare new lawyers for the demands of the modern world. At several law schools, including the Faculty of Law, University of Windsor, students are required to take at least one course in transnational law. Public international law tends to be central in the list of transnational courses. The area also offers the rich scholarship of comparative and private international law, as well as the study of pluralism and non-state law.

An emphasis on justice and accessibility supports this wide approach. Law is not solely about governments and institutions, but must serve society. The transnational perspective poses questions of accountability, inclusiveness, the definition of law and its function in the public interest, in a world in which public policy does not end at national borders. Throughout, the inquiry involves issues of justice

$4 \quad$ Morguard Investmants Ltd v De Savoye, [1990] 3 SCR 1077, 76 DLR $\left(4^{\text {th }}\right) 256$.

5 Robert Wai, "In the Name of the International: The Supreme Court of Canada and the Internationalist Transformation of Canadian Private International Law” (2001) 39 Can. YB Intl L 117.

$6 \quad$ Club Resorts Ltd V Van Breda, 2012 SCC 17, [2012] 1 SCR 572, at para 74.

7 Myra J Tawfik, "No Longer Living in Splendid Isolation: The Globalization of National Courts and the Internationalization of Intellectual Property Law” (2007) 32 Queen’s LJ 573; Reem Bahdi, “Globalization of Judgment: Transjudicialism and the Five Faces of International Law in Domestic Courts” (2002) 34 Geo Wash Intl L Rev 555.

8 Peer Zumbansen, "Transnational Comparisons: Theory and Practice of Comparative Law as a Critique of Global Governance” Research Paper No. 1/2012, Comparative Research in Law \& Political Economy, Osgoode Hall Law School, online: SSRN <http://papers.ssrn.com/sol3/papers.cfm?abstract_id=2000803> at 6. 
and participation, dealing with the interactions of domestic and international systems, and the actual legal experience of cross-border reality. 